\title{
Resource-rich countries, clean energy and volatility of oil prices
}

Book or Report Section

Accepted Version

Kalyuzhnova, Y. (2018) Resource-rich countries, clean energy and volatility of oil prices. In: Kalyuzhnova, Y. and Pomfret, R. (eds.) Sustainable Energy in Kazakhstan Moving to cleaner energy in a resource-rich country. Routledge. Available at http://centaur.reading.ac.uk/67910/

It is advisable to refer to the publisher's version if you intend to cite from the work. See Guidance on citing.

Publisher: Routledge

All outputs in CentAUR are protected by Intellectual Property Rights law, including copyright law. Copyright and IPR is retained by the creators or other copyright holders. Terms and conditions for use of this material are defined in the End User Agreement. 


\section{CentAUR}

Central Archive at the University of Reading

Reading's research outputs online 


\section{Part one: Setting the scene}

\section{Chapter 1}

\section{Resource-rich countries, clean energy and volatility of oil prices}

Yelena Kalyuzhnova

The energy mix for any country is a complicated issue, which should be supported by the 'correct' state energy policy. This process is especially challenging in resource- rich countries, where the temptation to use fossil fuels that are readily available becomes much easier, particularly during a period of lower oil prices. Although the beginning of a shift towards cleaner energy possible to track in a number of resource-rich countries including Kazakhstan. This chapter is discussing the fundamental questions related to renewables in Kazakhstan: economic, financial and geographical as well as policy issues from the long-term stability of the present development model.

\subsection{Renewables: to be or not to be?}

World oil prices are notoriously volatile. As Figure 1.1 clearly shows there was an increase in world prices in the first decade of the 2000s, followed by a fall, recovery and then uncertainty from 2009 until mid-2014. There was almost a decade of the high oil prices, followed by a drop of more than a half between June 2014 and January 2015, which only slightly picked up in May 2016, dropped again by around 10\% after the UK's 'Brexit' vote on 23 June 2016 and then increased to US\$50/bbl. Such volatility has caused companies and countries to reconsider and to re-assess their energy choices. The energy mix for any country is a complicated issue, which takes into account the country's resource endowment and its 
accurate assessment of the cost of energy. Countries also have to take into account not only the volatility of oil prices, but also the economic implications of such uncertainty. Understanding what this means for longer term trends is also crucial (Jacobson and Delucchi, 2011).

[Insert Figure 1.1 here]

Although oil prices are low at the time of writing, we argue that they do not reflect the true costs of fossil fuels, since they do not take into account the full range of negative impacts associated with their use. Emissions from the burning of fossil fuels cause air pollution, which has a profoundly negative impact on the health and productivity of millions of people across the world. According to World Health Organization (WHO) estimates, around 7 million premature deaths are annually linked to air pollution (WHO, 2014). In the current situation of lower fossil fuel prices, there is an opportunity to adjust prices with the aim of take into account the harmful local and regional impacts of such energy use, in particular on human health.

The sharp decline in oil prices in 2014 has raised the question of whether the change in energy mix of resource-rich countries will be stalled by cheaper and more affordable oil and gas or, despite all odds, they will continue their quest towards a more integrated energy mix with potential growth of the renewables sector. In the past it has been a concern that the use of renewables is an unreliable option (e.g. Nogee et al., 1999). The main argument focuses on the recurrent patterns of some types of renewable energy: wind blows only intermittently and the sun does not shine all of the time. However, this becoming less of an issue, since the role of gas in the electricity market is increasing and this provides an ideal complement to the 
generation profile of renewable energy technologies (RETs). In addition, there is a growing trend towards the development of energy storage technologies. So, hopefully, in the years ahead utility-scale solutions will be implemented that should minimise concerns regarding the uptake of renewable energy generation.

On the other hand, the last decade has been characterised by a number of studies that clearly made a case for large-scale renewable energy plans (Jacobson and Masters, 2001; Hoffert et al., 2002; Czisch and Schmid, 2004; etc.). There are a number of drivers towards renewable energy sources (RES), which are all related to the long-term future. One of them is clearly related to the desire of governments to establish secure local supplies and to protect their economies from the volatility of world oil prices, and to form policy frameworks worldwide that aim to decarbonise the economy in response to climate change and pollution concerns. The other drivers include the problems of managing hard-to-reach or absent resources (in the case of resource-poor countries), and finite resources (in the case of resource-rich countries). The requirement for increased electricity generation could also add to the list of the drivers for renewables, since the emerging gap in supply and demand that needs to be closed continues to grow.

Although, at the time of writing, oil prices are low, there is a good rationale to expand investments in renewable energy sources for electricity production (RES-E). Sustainable development of a country in the long term requires a reduction of dependence on fossil fuels, which ultimately will lead to a reduction in greenhouse gas (GHG) emissions. In this respect, governments need to produce robust plans and have the political determination to make such changes. However, for resource-rich countries this might not be an easy option, since the temptation to use fossil fuels will be always there. There is a notion that cheaper oil competes 
directly with renewable energy for electricity production. This is not true, cheaper oil can bring lower natural gas and coal prices with wider impacts.

Oil itself barely features in electricity production globally, and technologies such as solar photovoltaics and wind energy are therefore not affected by the oil price itself. However, lower natural gas prices associated with cheaper oil can change electricity choices: strengthening the near-term case to switch from coal to gas and reducing electricity prices, while making renewable energy source less cost-competitive in the short run. In the long term, however, a shift to gas cannot depend on the indirect impact of lower oil prices, but would require lower fundamental costs and improved availability of natural gas itself.

(Klevnäs et al., 2015: 2)

The attractiveness of RES is also related to their falling costs, which make these costs less volatile than the fluctuation of world oil prices. Oil can contribute to lower natural gas and coal prices, which will have wider implications. Consumers would significantly benefit from oil prices in low-carbon scenarios, since the energy mix would be more balanced.

Finally, there is a problem with reducing petroleum subsidies, especially in the oil-exporting countries. In terms of both the micro- and macro-economic effects, Kosmo (1987) shows that the assumed benefits of such subsidies, which may include economic stimulation, inflation control and enhanced trade performance, are in reality not the true effects. On the one hand, there is a danger that subsidies could increase unemployment since energy might be substituted for labour, and this would create over-investment in energy-intensive industries at 
the expense of other sectors. In addition, energy subsidies also translate into forgone revenues and the inefficient use of energy.

As Klevnäs et al. (2015) indicated energy efficiency and alternatives to fossil fuels have already reduced the pressure on fossil fuel markets. The current low oil prices provide a chance to escape 'stranding' of assets (this is a financial term, which means that something that is not performing as well as expected and must be indicated on a company's balance sheet as a loss of profit), since the low oil prices might send a signal to the governments of resource-rich countries to seek alternative sources of revenues rather than the production of oil. Low oil prices since 2014 have led producers to reduce their investment in hydrocarbon development. There is less money for new projects, less money for exploration and more focus on reducing operating costs; some producers are reducing their returns to shareholders and major global projects are on hold. This creates an opportunity both to avoid future 'stranding', and to avoid the trap of commitment to future fossil fuel. Around five years ago, the concept of stranded assets in the sense of 'unburnable carbon' emerged. The idea that 'some assets, specifically hydrocarbons, will inevitably be stranded and left undeveloped as the world reduces its hydrocarbon consumption in order to avoid the risks of climate change' (Butler, 2015) is debatable and requires more analysis and reflection.

\subsection{Building a green economy in an oil- and gas-producing country}

For decades, scientists, policy-makers and economists have been discussing the idea of a more sustainable economy (Meadows et al., 1972). In the last few years sustainability has become a key part of the global agenda. This is because the latest scientific research results, and the realities of environmental devastation and climate change, have made it clear that the perception, concept and economic model of long-term development need to change. This is 
why, in 2012, the major United Nations Conference on Sustainable Development (Rio+20) had a central scheme - the green economy (UNEP, 2011). The green economy project (GEP) was introduced and many scientists and environmentalists have aimed to help the political and economic actors 'to acknowledge the value of environment, submitting nature to the logic of the market (and the financial industry)' (Boehnert, 2015: 3). In preparation for Rio+20, the government of Kazakhstan aimed to integrate this programme into the mainstream economy and develop energy projects that would relate both to core business and green economy principles. So, the green economy concept was embedded in the government of Kazakhstan's Green Bridge programme, which stresses the importance of low-carbon development and the 'greening' of industry and technologies. The Kazakhstani government sees this programme as a mechanism to unlock the benefits of collaborative action on the green economy (Yessekin, 2012).

Throughout the 2000s, Kazakhstan's resource-dependent development strategy enabled significant poverty reduction and employment growth across a range of services and low productivity sectors. Research has identified that national and regional industrial policies since the 2000s have achieved only modest success in counter-balancing resource dependence or incentivising economic diversification and innovation-led growth (Kalyuzhnova, 2008; Kalyuzhnova and Patterson, 2016; Kalyuzhnova et al., 2016). A new period of low commodity prices therefore raises questions about the sustainability of further economic growth and poverty reduction. In 2012, the president of Kazakhstan stated the need to develop renewable energy and green technologies, but progress so far has been muted.

Economic development can be defined as a process whereby mental models condition cognitive/behavioural path-dependence and capacity for change (Mantzavinos et al., 2004; 
North, 2005). This, however, might not be a smooth process as institutional parameters, determined by political-economy and social processes, co-determine the extent to which changes in one part of a system are able to facilitate adjustments in other parts of the economic system. Of particular interest in Kazakhstan are the opportunities and barriers to using its mineral wealth to facilitate green and knowledge/technology employment and technological transition. At a practical level, it is necessary to begin by analysing and mapping the formal organisational and institutional framework of the energy-specific sectoral innovation systems; this stage could be defined as the institutional theme/stage.

Key analytical dimensions of the innovation and diversification process relate to the role of networks, informal institutions, perceptions of risk and risk aversion at different stages in the selection/innovation process. These stages of movement towards a greener economy could be defined as transitional and entrepreneurial themes/stages where the government will engage with key stakeholders in regulation, finance and industry, and explore the complexities of their interaction. The transitional theme/stage should focus on behavioural regularities and selection criteria that may introduce biases in technology and the innovation processes. The entrepreneurial theme/stage further engages with strategies employed by innovators in the oil and gas industry when dealing with public and private bodies.

Central concerns to industrial policy-making are threefold: firstly, the volatility and sustainability of the resource-driven development model; secondly, avoiding the 'middleincome trap'; and, thirdly, structural barriers to increased value-added production, labour productivity, industrial diversification, and innovation- and entrepreneurship-friendly regulation. ${ }^{1}$ 
All of these above-mentioned factors would create a clear framework for transition to a greener economy in Kazakhstan.

\subsection{Why should renewable energy sources be developed in Kazakhstan?}

The question that arises is, why should RES be developed in Kazakhstan, when it has a large reserve of fossil fuel? There are several reasons for this.

Firstly, Kazakhstan enjoys suitable geographic and climatic features and has potential for solar energy production (as long as the sun keeps on shining) as well as for wind. It is a well known fact that sun's energy is abundant; however, Kazakhstan needs to have the technology to capture it. This would allow for local decentralised control over power. Another strong advantage is that there no GHG emissions with solar power (except some that are created in the manufacture of the technology). Similar advantages apply for wind power. Wind power is renewable (as long as the wind blows) with no GHG emissions once the relevant equipment has been made and installed. As in the solar case, wind power can allow local decentralised control over power, as well as produce local profit from electricity sales. After the initial investment in wind power, which has high start-up costs, the costs reduce.

Secondly, renewable energy will contribute towards reducing GHG emissions and consequent climate change.

Thirdly, RES can reduce the amounts of oil and gas used in the production of electricity locally, and thus it is possible to make better use of these resources in more profitable fields. 
Finally, the renewable energy industry can contribute to economic diversification and job creation.

Although Kazakhstan possesses significant wind, solar, hydro and biomass potential, at the present time these resources have not been developed due a range of technical, institutional, social and economic barriers (Karatayev and Clarke, 2014; Karatayev et al., 2016).

\subsection{From oil rich to renewables rich: Kazakhstan's energy shift}

The implications of the global shift to cleaner energy, for a country whose economy has centred on hydrocarbon exports, is an interesting topic to consider. In Kazakhstan, there is a growing demand for alternative energy sources because of concerns related to the high environmental impact caused by the energy sector (Dadabaev and Naurzbayeva, 2014). There are a number of programmes, concepts and legislative documents related to sustainability and transition to a greener economy. Two aims are pursued, namely to regulate the issues related to the diversification of the country's energy mix and also to encourage the reduction of GHG emissions and the introduction of new technologies. ${ }^{2}$ The programme stressed the importance of developing the rational and efficient use of renewables, as well as the creation of centres for the sharing of international expertise in energy and resource saving.

Back in 2007 the concept and the definition of 'green growth' was introduced in Kazakhstan by the government (National Sustainable Development Strategy 2007) and was later adopted in the Zhasyl Damu Green Development Strategy (2010) with the aim of transition to a

resource-efficient 'green economy' (Salimzhanova et al., 2013). The Presidential Decree of 30 May $2013,{ }^{3}$ identified the targets for the share of alternative energy sources in power generation (solar, wind, hydropower, nuclear power plants). For example, solar and wind 
power plants should meet of $3 \%$ of total energy production by $2020,30 \%$ by 2030 and $50 \%$ by $2050 .^{4}$

The challenge for Kazakhstan, which should be urgently tackled, is that so far 'economic growth has driven increased demand for energy services, making the construction of additional generating capacity increasingly necessary for enabling sustained growth. In this context, renewable energy resources are becoming an increasingly attractive option to help bridge the demand-supply gap (Karatayev and Clarke, 2016: 491). An interesting statement has been made by Kazakhstan's president, 'The era of hydrocarbon economy is coming to its end. We face the beginning of a new era where human activities will be based not so much on oil and gas, but on renewable energy sources' (Nazarbayev, 2012). This statement has very much defined the course of the country for the future. The renewable energy industry can contribute to economic diversification and job creation in the country, which aspires are to become one of the 50th the most competitive nations in the world. What policies are needed to advance renewable energy? To meet its obligations under the Kyoto Protocol, Kazakhstan has agreed to reduce its carbon emissions by $15 \%$ by 2020 and by $25 \%$ by 2050 , compared to its 1992 level. The 2013 National Concept, ${ }^{5}$ focuses on moving the economy and power sector towards sustainable development and aims significantly increase the share of renewable energy in electricity generation in the overall energy mix of the country.

While the government is adopting new legal frameworks to encourage the transition towards renewables there are still significant barriers. Karatayev and Clarke (2016) have pointed out that low electricity tariffs, transmission losses and inefficient technologies, along with a weak regulatory and legal framework and risky business environment, are the main impediments for adoption of RETs. Overall the main obstacles to adoption of green technologies can be 
divided into four groups: (1) commercialisation barriers (which the new technologies are facing in the competition with the old technologies); (2) market barriers (e.g. lack of information, lack of access to capital and high transaction costs for making small purchases); (3) price distortions (these come from subsidies and unequal tax burdens between renewables and other energy sources); as well as (4) failure of the market to appreciate and understand the public benefits of renewables.

From our point of view this list could be continued and there are other obstacles that Kazakhstan specifically needs to address: a lack of awareness of the opportunities associated with renewable energy; a lack of technical expertise and capacity; insufficient governmental support to overcome high initial financial and capital requirements; and investment disincentives due to subsidies of other energy sources (primarily fossil fuels).

The financial barriers that are currently acting against the rapid adoption of RETs include the low price of electricity in the country; uncertainties with the long-term power purchasing tariffs; difficulties in attracting foreign investment (which is highly desirable not only in the financial sense but, even more importantly, because of the access gained to technology and expertise); a lack of access to credit for both consumers and investors; and lack of energy project finance expertise in banks. There are certain conditions for public and private investment. For public investment to occur the government needs to develop a clear strategic plan and have clear expectations regarding the effective return on the investment. Private investment requires some control over size (since renewables projects and companies are, as a rule, small and they have limited resources to invest compared to large generation companies and have limited possibilities to communicate directly with customers, negotiate 
favourable conditions with larger market players or participate in regulatory or legislative proceedings) and certainly revenues.

Institutional barriers include the absence of a clear national programme for renewable energy development; a lack of specific action plans and instruments; and a lack of concrete competitive legislation and regulation relating to the newly developed renewable energy market. Given the increasing success of the oil and gas sector, Kazakhstan will require significant government leadership to meet its vision for 2050 .

Finally, RES can have significant impacts on the quality of the local environment and public health. However, the deployment of RETs in transitional economies, which lie between mature electricity markets in OECD nations and developing country status, remains a significant challenge. Kazakhstan typically has extremely high energy use per unit of GDP, acute developmental needs and fossil fuel endowments large enough to enable net energy exports. In this context, significant renewable energy potential may exist, but fail to be taken up due to economic, institutional, technical and governance barriers, which are difficult to surmount without the drivers of reducing energy imports and where the unit price of energy is particularly low due to easy access to fossil fuels.

The overall conclusion of this chapter is that opportunities for structural change in energy systems remain - even with low oil prices. Countries may need to adjust their energy policies in response to the new situation. There are certain conditions that are required for the successful transition to a low-carbon economy. With natural gas prices dropping along with oil prices, governments may wish to consider an expanded role for natural gas in their energy supply, including using it as a replacement for coal in the power sector. Renewable energy 
sources for electricity generation continue to offer significant promise, but require some protection from short-term movements in fossil fuel prices. The longer term development of alternatives to oil in the transportation sector still depends on policy support, and there is a risk that the current momentum will be dissipated if policy is weakened. In the long run, low fossil fuel prices could be not a challenge, but one of the resulting benefits of low-carbon policies taking the pressure off fossil fuel prices.

\subsection{Conclusions and policy implications}

A major concern in Kazakhstan is the long-term sustainability of the present development model, which is reflected both in the literature and in recent Kazakhstani policies and presidential decrees. A key question is how to design the incentives within Kazakhstan for businesses to transition from a resource-based to an innovation-led growth model. We have suggested a focus on three core themes: (1) institutional - in order to explore the incentives and barriers for the traditional oil and gas sector to diversify into renewables; (2) transitional - to facilitate the move from oil and gas to renewables, focusing on the role of networks, risk perception and risk aversion at different stages in the selection/finance/innovation process; and (3) entrepreneurial - ICT-enabled education and capacity building in diversification strategies and green start-ups for all stakeholders.

The Kazakhstani government should be clear about the objectives related to these themes/stages: namely to map and analyse the institutional constraints on innovation in green energy; to identify mechanisms to facilitate diversification from resource-led growth to innovation-led growth; to propose policies for overcoming barriers to green energy; to develop the continuous professional development scheme for civil servants, entrepreneurs and key stakeholders; to encourage sustainable growth; and to increase social welfare through 
green-energy job creation. The whole process should be implemented from the multiple perspectives of a transition to a sustainable green economy. The government should operationalise these issues by analysing the sectoral innovation systems in the oil and gas and in the green energy/technology sectors (as examples of the two growth models).

The greener economy in Kazakhstan could become a tool for promoting sustainable development and economic growth, and therefore this will help to eradicate poverty, create a pool of green jobs and fight inequality in one the most deprived regions of the country. Kazakhstan's energy sector is facing an extraordinary combination of dire problems in providing conditions required for a more balanced energy mix for the economy. Robust energy policy by the government will be vital to solving the multiple challenges and overcoming barriers, as well as encouraging the massive investment needed from the private sector and international donors. But time is running out. The challenge of transition to the greener economy is becoming a matter of urgency.

\section{References}

Boehnert, J. (2015). The green economy: reconceptualizing the natural commons as natural capital. Environmental Communication 10(4), 395-417.

Butler, N. (2015). Climate change and the myth of stranded assets. FT.com. Sep 28. http://blogs.ft.com/nick-butler/2015/09/28/climate-change-and-the-myth-of-strandedassets [Accessed 11 Aug 2016].

Czisch, G. and Schmid, J. (2004). Low cost but totally renewable electricity supply for a huge supply area: a European/trans-European example. http://transnationalrenewables.org/Gregor_Czisch/projekte/WWEC2004.pdf [Accessed 12 August 2016]. 
Dadabaev, T. and Naurzbayeva, A. (2014). Prospects for alternative energy development. policy in Kazakhstan: The case study of wind power development. Chapter 7 In J. Li and C-J. Yang (eds.) Globalization, Development and Security in Asia. The Political Economy of Energy. Volume 3. pp. 159-80. New Jersey: World Scientific.

Hoffert, M. I., Caldeira , K., Benford, G. et al. (2002). Advanced technology paths to global climate stability: energy for a greenhouse planet. Science AAAS 298, 981-7.

Jacobson, M. Z. and Delucchi, M. A. (2011). Providing all global energy with wind, water, and solar power, Part I: Technologies, energy resources, quantities and areas of infrastructure, and materials. Energy Policy 39, 1154-69.

Jacobson, M. Z. and Masters, G. M. (2001) Exploiting wind versus coal. Science AAAS 293, 1438.

Kalyuzhnova, Y. (2008). Economics of the Caspian Oil and Gas Wealth: Companies, Governments, Policies. Basingstoke: Palgrave Press.

Kalyuzhnova, Y. and Patterson, K. (2016). Kazakhstan: long-term economic growth and the role of the oil sector. Comparative Economic Studies 58(1), 93-118.

Kalyuzhnova, Y., Nygaard, C. A. Omarov, Y. and Saparbayev, A. (2016). Local Content Policies in Resource-rich Countries. Palgrave Press.

Karatayev, M. and Clark, M. L. (2014). Current energy resources in Kazakhstan and the future potential of renewables: a review. Energy Procedia 59, 97-104.

Karatayev, M. and Clark, M. L. (2016). A review of current energy systems and green energy potential in Kazakhstan. Renewable and Sustainable Energy Reviews 55, 491-504.

Karatayev, M., Hall, S., Kalyuzhnova, Y. and Clarke, M. L. (2016). Renewable energy technology uptake in Kazakhstan: policy drivers and barriers in a transitional economy. Renewable and Sustainable Energy Reviews 66, 120-36. 
Klevnäs, P., Stern, N. and Frejovam, J. (2015). Oil prices and the new climate economy. The New Climate Economy. www.seiinternational.org/mediamanager/documents/Publications/NEW/NCE-SEI-2015Oil_prices.pdf [Accessed 12 Aug 2016].

Kosmo, M. (1987). Money to Burn. The High Costs of Energy Subsidies. Washington, DC: World Resources Institute.

Mantzavinos, C., North, D. C. and Shariq, S. (2004). Learning, institutions and economic performance. Perspectives on Politics 2(1), 75-84.

Meadows, D. H., Meadows, D. L. Randers, J. and Behrens W. W., III (1972). The Limits to Growth. Universe Books.

Nazarbayev, N. (2012). Address by the President of the Republic of Kazakhstan, Leader of the Nation, N. A. Nazarbayev. Strategy 'Kazakhstan-2050'. New political course of the established state. December 14. www.kazembassy.org.uk/en/pages/page/20 [Accessed 12 Aug 2016].

Nogee, A., Clemmer, S., Paulos, B. and Haddad, B. (1999). Powerful solutions. 7 ways to switch America to renewable electricity. January. Cambridge, MA: Union of Concerned Scientists.

http://www.ucsusa.org/sites/default/files/legacy/assets/documents/clean_energy/psall.pdf [Accessed 12 Aug 2016].

North, D. C. (2005). Understanding the Process of Economic Change. Princeton University Press.

Salimzhanova, A. S., Sardinas, J. C. and Yanovskaya, O. A. (2013). 'Green growth' in Kazakhstan: political leadership, business strategies and environmental fiscal reform for competitive system change. International Journal of Social, Behavioral, Educational, Economic, Business and Industrial Engineering 7(12), 3009-3016. 
United Nations Environment Programme (UNEP) (2011). Towards a green economy:

pathways to sustainable development and poverty eradication.

http://web.unep.org/greeneconomy/sites/unep.org.greeneconomy/files/field/image/gre

en_economyreport_final_dec2011.pdf [Accessed 12 Aug 2016].

World Health Organization (WHO) (2014). 7 million premature deaths annually linked to air pollution. News release. 25 March.

www.who.int/mediacentre/news/releases/2014/air-pollution/en [Accessed 12 Aug 2016].

Yessekin, B. (2012). Green Bridge Partnership Programme: A mechanism to unlock the benefits of collaborative action on green economy.

www.unece.org/fileadmin/DAM/env/cep/CEP-19/ppp/CEP-

19Item6_c_GE.Kazakhstan.e.pdf [Accessed 12 Aug 2016].

\footnotetext{
${ }^{1}$ See for instance Presidential Decree 874, 2014.

${ }^{2}$ The Concept of the Republic of Kazakhstan on the Transition to Sustainable Development for 2007-2024 (Government Resolution No. 216, 14 November 2006) could be highlighted.

${ }^{3}$ The Presidential Decree of 30 May 2013, No. 577 'On the Concept of the Transition of the Republic of Kazakhstan to a Green Economy'

4 'Efficient Use of Energy and Renewable Resources of the Republic of Kazakhstan for Sustainable Development until 2024' was designed to meet the government's goals.

5 'National Concept for Transition to a Green Economy up to 2050', 2013.
} 


\section{Chapter 1: Figure captions}

Figure 1.1 Brent crude oil, monthly price, 1990-2016, US\$/bbl (Bloomberg) 
Figure 1.1

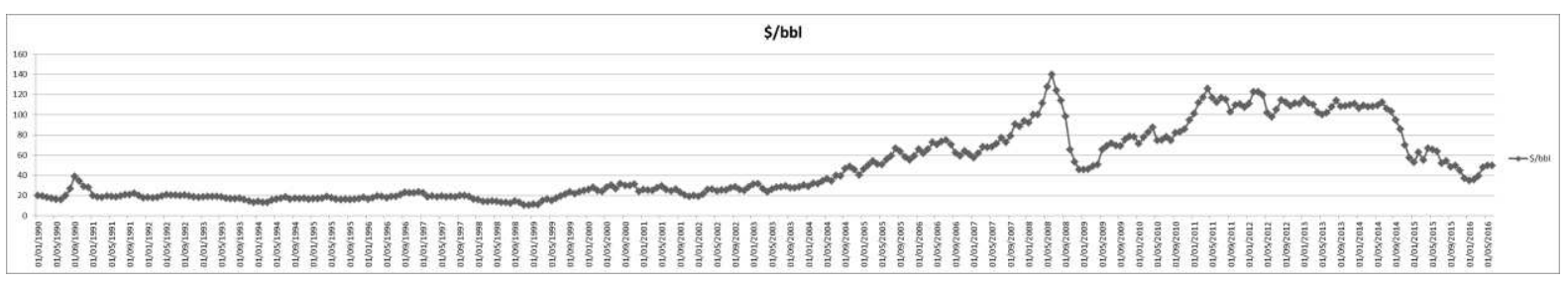

